\title{
Outline of an Effective GPS Education Trail Methodology
}

\author{
Stefanie ZECHA \\ Justus Liebig University Giessen / Germany·stefanie.zecha@gmx.de
}

This contribution was double-blind reviewed as full paper.

\begin{abstract}
GPS educational trails are enjoying increasing popularity. The challenge for educators is now to develop more effective GPS education trails. This article tries to define a methodology for devising such trails. With an intensive literature study, the most important aspects and outcomes are selected and described. A grid with which to assess the learning effectiveness of a GPS education trail based on the points drawn from the literature is then proposed.
\end{abstract}

\section{The Increasing Popularity of GPS Education Trails}

Since the opening up of the Global Positioning System (GPS) for private use in 2001 (TELAAR 2007), people can use satellite navigation almost everywhere. At the same time, the number of mobile computing and spatially-enabled devices is also accelerating the access to digital geographic information, meaning that satellite navigation and geomedia will be used more and more (LUDE et al. 2013). As a consequence, Geomedia competence and the capacity to interpret digital geographic information are becoming key qualifications in many different disciplines. Over the last year, the number of GPS education trails (ZECHA 2012,3 ) rose considerably, especially in the field of environmental education (ZECHA \& SCHILlER 2014). People of different disciplines (HOF 2013, FROMMHOLD 2011, KOLLER 2010) use the word GPS education trail. There is not yet a single definition for this word. However, it usually involves the participant finding the learning area with the help of GPS coordinates (see chapter 2.1). Educators like to use this form of information transmitting, as it is attractive to children. Youngsters, who are normally away from nature and traditional environmental education programs, can experience nature with the help of GPS devices. These mobiles are a kind of 'bridge to nature' for them. (NAVI NATUR 2010, LUDE et al. 2013) University tutors for example use this method to transmit knowledge from the university classroom to students located in outdoor situations (HOF 2013).

This article will outline a general basis for GPS education trails, rendering them most effective for learning. Research derives from the question:

"How can GPS education trails be created to get the most positive learning outcome?"

- What are the specific characteristics of a GPS education trail?

- What are the specific characteristics of a cache? 
All previous articles in the field tend to focus especially on the transmitting of knowledge in a specific domain (NAVI NATUR 2010, LUDE et al. 2013, GRÜNDEL 2013, BURT 2010, HOF 2013). LUDE (2013) shows how GPS education trails can be used in environmental education, but he does not totally integrate the standards of trail didactics or the didactic of excursions, which are important for the enhanced learning effect. His publication focuses more on the environmental education aspects. At the end, the author presents a gird, which enables the analysis of GPS education trails with regards to learning effectiveness.

\section{Creating Good GPS Education Trails: A Challenge}

To develop a methodology for designing education trails, the author used existing methods like didactics of geography excursions (LÖßNER 2011, BöING \& SACHS 2007), path didactics (MEGERLE 2003 / 2007, LUDWIG 2005), nature interpretation (LEHNES 2006, LEHNES \& GLAWION 2002), mobile location based learning (HolzINGER 2010, RoBES 2009, SEITZ 2011, SCHNITZER 2012), and with problem based learning (MANDL 2003). At the end of this chapter, there will be an editable form to analyze GPS education trails for their learning effectiveness.

\subsection{A Short Literature Overview of GPS Education Trails}

GPS education trails integrate the geocaching method. "Geocaching is a high-tech treasure hunting game played throughout the world by adventure seekers equipped with GPS devices. The basic idea is to locate hidden containers, called geocaches, outdoors, and then share your experiences online" (GROUNDSPEAK 2010). The method of geocaching wants to guide people to especially attractive places, which they can find with the help of GPS coordinates, which are mostly posted online, and a GPS device (GRÜNDEL 2013; wWW.GEOCACHING. $\mathrm{DE})$. This method is quickly spreading in the education field, in both the formal and informal sector (KOLLER 2010; WWW.EDUNAUTEN.NET). If there are more geocaches which treat the same content from a different perspective and the producer organizes the caches in one path, it is called a GPS trail. GPS education trails are on the increase, especially the ones which focus on a certain theme. Thereby each cache treats one aspect of the main theme. (WWW.EDUNAUTEN.NET; FormMHOOLD 2011) Authors call this kind of cache an educache. The learning subject is outside the digital media; it is in the location itself. The educache has to be more than a mere location if it is to initiate a learning process. The location itself must provide an opportunity to ask questions and give the possibility to start a thinking process, as described above (www.educache.net).

\subsection{Integration of Different Didactical Aspects}

To create a good GPS education trail, three different aspects need to be taken into account: 1. Integration of different learning contents, 2. Physical construction of a GPS education trail, 3. Remarks on the cache stations and their environment. These aspects have to be considered independently. The author focuses on problem based and local based learning, because the learning effect will be the highest in combining these two approaches. While problem based learning concentrates only on the preparation of the content, local based learning also integrates the use of new media outdoors, and also takes into account software learning. 


\subsubsection{Problem based learning}

Psychologists talk about inert knowledge in the learning process, which means that people have problems in applying their knowledge to new problem situations beyond the instructional context (MANDL 2003). Problem-based learning provides the possibility of minimizing this drawback, and enabling the activation of previous knowledge. Since MANDL (2003), problem-based learning has covered five aspects: Active learning processes, selfassessment skills, situative learning (this goes along with the location based learning), and constructive and social processes (MANDL 2003, 9). Problem-based learning starts from the students' personal and direct experiences and gives them something to do, instead of something to learn. The educator's sole role is to place the students in action so that they can reflect on the relations involved in the object of study themselves. Therefore, students should face "real" problems not simulated or ridiculous problems that would propel them to action (CUNHA \& DEWEY 1994). Students will make strong connections between concepts when they learn facts and skills by actively receiving information (GALLGHER 1997, RESNICK \& KLOPPER 1989). By trying to answer questions, students will be involved in independent thinking and working. For this reason, the title of the cache should be a question; indicating that this method is being used. As problem-based learning is used with new medias like mobiles, the planers should also integrate in the learning process location based learning, which also regards software learning.

\subsubsection{Location-based Learning}

GPS education trails include location-based learning. This is an umbrella term for learning scenarios, services, and learning software which are especially related to the current residence of learning (PEASCHKE \& PARDEY \& SEITZ 2013, SEITZ 2011). Location-based learning provides the user with a new way to experience the area. People find out about special local places with the help of their mobile phones, GPS coordinates and special map information. A key factor of location-based learning is that it compares favourably with a neutral form of information transmitting, especially for people who are used to digital equipment and for whom access to digital technology is normal (SCHNITZER 2012). Typical for the case of local-based learning is the connection with a game or gaming elements, because it creates a degree of emotional attachment for the learner. GEE (2009) describes gaming as "psyching out how rules can be used for one's advantage to accomplish goals to which one is personally and emotionally attached" (GEE 2009, 70).

These games have many interactive possibilities, and this is a first possibility for the caches of the GPS education trails. Another aspect of location-based learning are micro learning scenarios, a style of learning which suits many people and can also be found in the caches. The reason for this is that Internet users are used to small, internet-provided information, procured by googling terms. These people are used to working with the "information appetizer", "learning appetizer" or "learning nugget" (ROBES 2009). This kind of learning environment provided by geocaches can provide such nuggets, especially as the tasks should not be too long. However, this kind of learning is not always sufficient. Generally, in location-based learning, the presentation of information is important with the help of the internet, but the preparation of the information is less important. It is crucial that technology is only a vehicle for learning. In order to integrate the learning aspect, it is therefore vital to incorporate "problem-based learning" (HOLZINGER 2010). 
The special relation of learning outside in nature can be created with the help of environmental interpretation.

\subsubsection{Environmental interpretation}

The learning methods outlined above should be used in combination with the method known as environmental interpretation. This kind of interpretation comes from the USA. It allows one to translate the language of natural phenomena into the language of people (LUDWIG 2003, 1). This method has the aim of communicating between the contemplator and the natural phenomena, and to create a connection between the phenomena, entering into the contemplator's world. For this you can use open questions (hence the connection to problem based learning), comparisons, or images, in order to give the contemplator a thought provoking impulse. In this way, the creator of the GPS education trail can realize an exciting presentation of facts and interrelationships, which force the visitor into their own thinking and acting (NUTZ 2003, 28 f). These aims compliment problem-based learning and location based learning. The aim of landscape interpretation is not only to provide facts, but also to impart deeper knowledge. The GPS education trail touches the participant emotionally; awakens them, so that they recognize the value of their surroundings (EDER \& ARNBERGER 2008, 53). A very important aspect is the active dialogue between the interpreter and the participant. The task of the interpreter is to build a bridge between the natural phenomena and the visitor. To reach this goal, the creator of the trail must be able to predict the perception and thinking of the visitors, so that he can integrate them. (LUDWIG 2003). This way of guiding people through nature has a profound impact on learning when used in conjunction with the other methods, because it integrates the visitor and addresses him personally. Environmental interpretation can also happen in the medial way with the help of GPS education trails. The caches have to have a direct connection to natural phenomena at the location. (MEGERLE 2003, 18).

\subsubsection{Didactics of excursion}

Another aspect of didactics which should inform our outline is the didactic of excursion. A good GPS education trail has three phases, as you can see in the didactics of excursions (HEMMER \& UPHUES 2009, RINSCHEDE 2009): preparation, performance, post-processing (figure 1).

\section{Preparation}

In the preparation phase, there will be organizational activities, in combination with the content, both didactical and methodological.

\section{Performance}

The performance is the participants' actual going through the GPS education trail (chapter 2.3). Each cache should only treat one subject, which is very obvious. The information should decrease with the length of the trail, because concentration decreases over time. According to the didactics of excursions, the first and the last locations are very important (BEYER \& HEMMER 2004). The last location is what people will usually remember best. In every area, the trail developer has to respect the guiding principle of excursions: Integration of the participants and motivation of the participants, but also the psychology of learning; the learning effect (GUDJONS 2008, 61 ff, HASSELHORN \& GOLD 2009, 64). 


\section{Post-processing}

The post-processing activities can occur in another place and should provide an opportunity to reflect on the process and to get deeper information.

\subsection{Physical construction of a GPS education trail}

Every GPS education trail consists of three steps: the preparation , performance (entrance, main and exit area) and post-processing. (Figure 1).

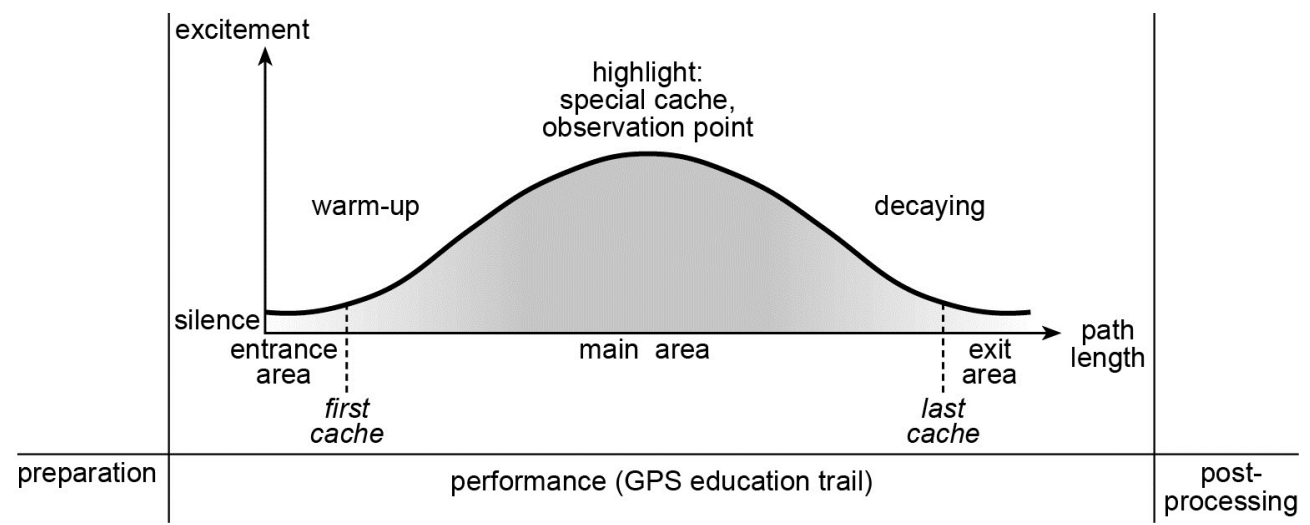

Fig. 1: The dramaturgy course of the visit of a GPS education trail (the author)

\section{Entrance Area}

The entrance area is the first contact point for the participants with the trail in reality. If they have had no preparation before, it is a kind of reception area. At the beginning of the trail, the participants should become familiarized with the topic. You can use elements of constructive didactics (BÖING \& SACHS 2007). The first step is for people to mentally 'arrive' at the trail. You can look into their personal relationship with the theme, and knowledge they already have (BöING \& SACHS 2007). In this way, they can get familiar with the theme. Then you give some short information about the main aims of the GPS education trail, the distance and difficulty of the trail, and whether it is a cycle way or the end is in another place. A map with the different cache locations and contact address could be included, even better if it is linked to a homepage. The following aspects are not directly connected to the learning aspect, but they make sure that people are primed for the trail and are starting a learning process. The area itself should be readily found and easily visible, perhaps with the possibility to sit, and a parking area for cars, or better still, a bus stop nearby (MEGERLE 2007).

\section{Main Area}

The main area is the course itself. It should be varied. Each cache should lead smoothly to the next. There should not be repetition. From the didactic of excursions, we know that each cache should communicate one aspect, so that each location is connected to one specific theme (BEYER \& HEMMER 2004). The organization of caches will be explained in detail later (chapter 2.4). The route has the function of communicating the landscape experi- 
ences and guiding the people to the cultural and natural highlights of the landscape. (ARNBERGER \& HAIDE 2005). The criteria for the distance of a GPS education trail is the audience, so GPS education trails for families are normally shorter than those for students. The distance is important, but also the difference in altitude should be taken into account. A good average distance is between two and four kilometers (MEGERLE 2003). The distance between different stations should be around 10 minutes, meaning you would find ten to fifteen caches on a three-kilometer trail (ENGELSCHALL 2012, 14).

\section{Exit Area}

Like the entrance area, the exit area also needs a special place, which can provide for the 'decay' in a nice area. (LUDWIG 2003). As with the beginning, the end of the GPS education trail should also be clearly marked in content and area. Otherwise, visitors may get confused. The most important message of the GPS education trail should be concentrated. The last impression is the most important because this is what the participant will remember. At the end, there should be a kind of special post-discovering, so that the participants can reflect on the learning aspects, but also their emotions during the GPS education trails. This increases the learning effect (BÖING \& SACHS 2007).

\subsection{Remarks on the Cache Stations}

The cache itself can be divided in different aspects: The learning methodology (chapter 2.2); the design of the content; the script and the technical aspects.

\subsubsection{Design of the cache Cache title}

The title can dictate whether the participant does the cache or not. Interesting titles arouse the attention of the participants to read the content in the cache and start a learning process. Authors should use interesting titles like "What is hidden beneath the grass?" Instead of "stone pit".

\section{Text Composition}

Independently of the possibilities which the web 2.0 offers, a closer look must also be taken at the text composition. You can find good examples in the path didactics. The textual content should be similar to a news article. The most important information should be at the beginning. The content should have a relation with the participants, offer examples from their lives, so that they have a kind of 'aha' effect. The text should be provoking and offer relationships. Simple sentences with few foreign words are better. Also personal addresses which challenge people to think along, make comparisons and interrogate their lives work best (LUDWIG 2005, WOHLERS 2003). One method to attract the participant is the use of storytelling, allowing information from the different caches to make a story (LUDWIG 2005, LEHNES \& GLAWION 2002). Too large bodies of text tend to give the impression that it takes some effort and time to deal with the cache. Even the summary might be ignored if at a first glance the panel as a whole does not look inviting. Research on self-guided trails in The Black Forest has shown that the German public considers a body of text consisting of roughly 170 words as appropriate. 200-250 words are mostly met, 251-300 are partly met, 301-400 are hardly met and 400 are not met at all (LUDWIG 2005, EDER \& ARNBERGER 2007). Homogenous design promotes recognition and makes learning easier. The content of the caches must be designed in such a way that the essential information can be seen at a 
glance. There can then be an outline through enumeration or chronologizing of the content. (LUDWIG 2005).

\section{Script}

Generally, you can divide the script into different families. Big letters are only good for the heading and not for the continuous text. In comparison to small letters, the big letters require more than $40 \%$ of the space. Left aligned text makes for easier reading than the justified style (LUDWIG 2005).

\section{Technical Aspects}

The task the participants have to solve also depends on the technical infrastructure of the GPS education trail. The lowest grade is one where the participants search for the location of the cache with the help of a GPS device or a mobile phone, and there people find a kind of cachebox. The next step is that people no longer find a cache box but use the method of mobile tagging (HEGEN \& GOLD 2010) with a QR code (Quick Response codes). If the mobile has no connection to the internet, the QR codes can be used like a classic cache. Instead of reading the cache letter, the code must be scanned to get the information. The next step is that the code is linked to a homepage with interactive tasks to bring together the different learning perspectives (chapter 2.2) with the programming standards, so that at the end the learning effect is the highest. Linking to online maps, historic information and video, and upcoming nature programs are also possible (FROMMHOLD \& MEWES 2011). QR Codes are very practical for a couple of different reasons. One is that even if $30 \%$ of the code is damaged, the content is still readable. (WESTERMANN 2013, HEGEN 2010). For GPS education trails, indirect codes are better. (HEGEN 2010, 35). The future lies in 4D QR Codes with colour and animation, so the data will be no longer be transferred by a picture, but by a film sequence. The most errors happen, when the code is poorly stationed. The optimal code depends on the distance of the user: A rule of thumb is that $10 \mathrm{~mm}$ is the minimum length of the edge of the code (WESTERMANN 2013, 58). The QR Codes can be particularly useful if they are linked to a homepage for evaluating the different caches (URBAN 2014).

The aspects covered here are all in the grid below. The grid allows the educator to evaluate the effectiveness of GPS education trails.

Tab. 1: Grid to evaluate a GPS education trail

\begin{tabular}{|c|c|c|c|}
\hline Aspects & Level & & \\
\hline & low & middle & high \\
\hline $\begin{array}{l}\text { Didactics of excur- } \\
\text { sion }\end{array}$ & GPS trail & $\begin{array}{l}\text { GPS trail; preparation or } \\
\text { postprocessing }\end{array}$ & $\begin{array}{l}\text { Preparation; GPS trail } \\
\text { postprocessing }\end{array}$ \\
\hline $\begin{array}{l}\text { Problem-based } \\
\text { learning }\end{array}$ & caches & $\begin{array}{l}\text { caches; preparation } \\
\text { orpostprocessing }\end{array}$ & $\begin{array}{l}\text { caches; preparation; } \\
\text { postprocessing }\end{array}$ \\
\hline Mobile learning & GPS and boards & GPS OR codes & GPS interactive OR codes \\
\hline $\begin{array}{l}\text { Landscape inter- } \\
\text { pretation }\end{array}$ & caches & $\begin{array}{l}\text { caches; prepara- } \\
\text { tion/postprocessing }\end{array}$ & $\begin{array}{l}\text { caches; preparation; } \\
\text { postprocessing }\end{array}$ \\
\hline
\end{tabular}




\begin{tabular}{|l|l|l|l|}
\hline $\begin{array}{l}\text { GPS trail as a } \\
\text { whole }\end{array}$ & walk through & develop & develop, use them \\
\hline $\begin{array}{l}\text { Physical construc- } \\
\text { tion of the trail }\end{array}$ & course & $\begin{array}{l}\text { Entrance area or exit } \\
\text { area; course }\end{array}$ & Entrance; course; exit area \\
\hline $\begin{array}{l}\text { Technical infra- } \\
\text { structure }\end{array}$ & GPS device & $\begin{array}{l}\text { tablet/computer/ } \\
\text { smartphone }\end{array}$ & tablet/computer/smartphone \\
\hline caches & numbers & $\begin{array}{l}\text { Numbers; titles or imag- } \\
\text { es }\end{array}$ & Numbers; titles and images \\
\hline Text in the caches & Only text & Text and interesting title & $\begin{array}{l}\text { Text, interesting title, relation } \\
\text { to the life participants }\end{array}$ \\
\hline
\end{tabular}

\section{Conclusions}

To summarize the most basic points of a methodology of GPS education trails, planners have to consider different learning methods, such as problem learning in combination with mobile learning, to achieve the highest learning effect. To integrate the environmental aspect in the cache, tasks also have to include the landscape around it. Looking at the GPS trail as a whole, it needs to be taken into account that there are processes before, during and after performance (as seen in figure 1). Some story should be developed for the GPS trail, with an arc of suspense, to attract the attention of the people till the end. The caches themselves, as well as their design, need to recognize the different learning methods, this means the text composition like interesting titles, script, length of the text. Thereby QR Codes offer a very interesting means, offering the possibility of using mobile learning more intensively. Table 2 is a form that can help to evaluate a GPS education trail for its effectiveness. The next step would be to look at existing GPS education trails, to find out in which aspects they use the different corner points of a methodology of GPS education trails. Moreover, this article enables the development of a GPS education trail that involves all these aspects and the evaluation of this trail.

\section{Bibliography}

Beyer, L. \& Hemmer M. (2004), Mit Schülerinnen und Schülern vor Ort - Grundlagen der Standortarbeit aufgezeigt am Beispiel des Potsdamer Platzes in Berlin. RAAbits Geographie, 43, 1-17.

BöING, M \& SACHS, U. (2007), Exkursionsdidaktik zwischen Tradition und Innovation Eine Bestandsaufnahme. Geographie und Schule, 167, S. 36-44.

BURT, L. (2010), GPS and Geocaching in Education. http://www.iste.org/images/excerpts/GCACHE-excerpt.pdf (20.04.2011).

CUNHA, M. V. \& DEWEY, J. (1994), Uma filosofia para educadores em sala de aula. $3^{\text {rd }}$ Ed. Petrópolis. Voze.

EDER, E. \& ARNBERGER B. (2008), Auf den Pfaden von Natur und Kultur. Wodurch werden Lehrpfade, Themen- und Erlebniswege zu attraktiven Destinationen? Wien, Bohlau. 
ENGELSCHALL, B. (2012), GPS Bildungsrouten im Regionalpark Wedler Au. In: Metropolregion Hamburg (Ed.), Natur als Abenteuer - GPS. Wedel (Eigenverlag).

Frommhold, A. \& Mewes, D. (2011), Mediale Bildungspfade. In: Winter, A. (Eds.), Spielen und Erleben mit digitalen Medien. Pädagogische Konzepte und praktische Anleitungen. München, Rheinhardt-Ernst Verlag, 82-103.

GEE, J. P. (2009). Deep learning properties of good digital games: How far can they go? In: RitTerfeld, M. \& Vorderer P. (Eds.), Serious games: Mechanisms and effects. New York, NY, Routledge, 67-82.

Gudjons, H. (2008), Handlungsorientiert Lehren und Lernen. Schüleraktivierung, Selbsttätigkeit, Projektarbeit. Bad Heilbrunn, Kleinhardt Verlag.

GRÜNDEL, M. (2013), Geocaching. Alles rund um die moderne Schatzsuche. Kassel, Welver Verlag.

Hasselhorn, G. \& Gold, H. (2009), Pädagogische Psychologie. Erfolgreiches Lernen und Lehren. Stuttgart, Kohlhammer.

Hegen, M. \& GolD, A. (2013), Mobile tagging. Potenziale von QR-Codes im Mobile Business. Hamburg, Diplomaica Verlag.

Hemmer, M. \& Uphues, R. (2009), Zwischen passiver Rezeption und aktiver Konstruktion. Varianten der Standortarbeit aufgezeigt am Beispiel der Großwohnsiedlung BerlinMarzahn. In: Dickel, M. \& GLASZE, G. (Eds.), Neue Wege der Exkursions- und Reisedidaktik: Vielperspektivität und Teilnehmerzentrierung. Berlin, Wichmann Verlag.

Hof, A. \& Michel, E. (2013), Promoting Spatial Thinking and Learning with Mobile Field Trips and eGeo-Riddles. In: JEKEL, T. et al. (Eds.), GI_Forum 2013 - Creating the GISociety. Berlin/Offenbach, Wichmann, 378-387.

Holzinger, A. (2010), Pervasive E-Learning. Neue Technologien unterstützen lebenslanges Lernen. In: Hohenstein, A. \& Wilbers, K. (Eds.), Handbuch E-learning. Köln, Deutscher Wirtschaftsdienst, 1-16.

KolLER, A. (2010), Geocaching - Ein Impuls für den GW-Unterricht?! GW- Unterricht, $119,1-10$.

LEHNES, P. (2006), Lehr-, Erlebnis- und Themenpfade Naturpark Südschwarzwald (Eigenverlag).

LEHNES, P. \& GLAWION, R. (2002), Landschaftsinterpretation - ein Ansatz zur Aufbereitung regionalgeographischer Erkenntnissen für den Tourismus. In: Zollinger, G. (Ed.), Aktuelle Beiträge zur Angewandten Physischen Geographie der Tropen, Subtropen und der Regio TriRhena. Freiburger Geographische Beiträge, 60, 313-326.

Lude, A., SchaAl, S., Bullinger, M. \& Bleck, S. (2013), Mobiles, ortsbezogenes Lernen in der Umweltbildung und Bildung für nachhaltige Entwicklung, Hohengehren, Schneider Verlag.

Ludwig, T. (2003), Grundlagen der Interpretation EU-Projekt, Topas Alfred Töpfer Akademie Schneverdingen.

LuDwIG, T. (2005), Grundkurs Natur- und Kulturinterpretation, Kurshandbuch. Werleshausen. http://www.interp.de/dokumente/kurshandbuch.pdf (15.04.2014).

LÖßNER, M. (2011), Exkursionsdidaktik in Theorie und Praxis : Forschungsergebnisse und Strategien zur Überwindung von hemmenden Faktoren. Gießen, Hochschulverband Geographiedidaktik.

MandL, H. (2003), Problemorientiertes Lernen und Lehren. Praxis Schule 5-10, 14 (5), 8-10. 
Megerle, H. (2003), Naturerlebnispfade - neue Medien der Umweltbildung und des landschaftsbezogenen Tourismus? Bestandsanalyse, Evaluation und Entwicklung von Qualitätsstandards. Tübingen.

NAVI NATUR (2010), GPS-Bildungsrouting. Methode zur Partizipation von Schülerinnen in einer Bildung für nachhaltigen Entwicklung (BNE). Lüneburg. Navi Natur.

NuTZ, M. (2003), Lehr-, Lern- und Erlebnispfade zur Umweltbildung. Natur erkennen, erleben, erhalten. Hochschulpraxis - Erziehungswissenschaft, 6, 1-91.

Peaschke, M. \& PARdey, C. \& Seitz, D. (2013), Location-based learning. In: Ludwig, L. et al. (Eds.), Lernen in der digitalen Gesellschaft - offen vernetzt, integrativ. http://dl.collaboratory.de/reports/Ini7_Lernen.pdf (24.03.2014).

RESNICK, L. B. \& KLOPFER, L. E. (1989), „Toward the thinking curriculum“. In: RESNICK, L. B \& KLOPFER, L. E (Eds.), Toward the thinking curriculum: current cognitive research. Reston., 1-18.

RinsCHEDE, G. (2009), Geographiedidaktik. Paderborn, UTB Verlag.

RoBES, J. (2009), Microlearning und Microtraining: Flexible Kurzformate in der Weiterbildung. In: HohensteIn, A. \& WILBERS, K. (Eds.). Handbuch E - Learning. Köln, Deutscher Wissenschaftsdienst, 1-19.

SCHNITZER, S. (2012), Junge Deutsche 2012/13. Bonn.

SEITZ, D. (2011), Mobile Spielformen und soziale Netzwerkgemeinschaften. In: WINTER, A. (Ed.), Spielen und Erleben mit digitalen Medien: Pädagogische Konzepte und praktische Anleitungen. München, Ernst-Reinhardt Verlag, 62-81.

URBAN, T. (2014), Quick-Response-Codes in den Nationalen Naturlandschaften Thüringens. In: Michel, U. et al. (Eds.), Digitale Medien in der Bildung für nachhaltige Entwicklung. Potentiale und Grenzen. München, 175-177.

WoHLERS, L. (2003), Methoden informeller Umweltbildung. München, Peter Lang Verlag.

Westermann, N. (2013), QR-Codes im Mobile Marketing optimal einsetzen, Berlin, epubli GmbH.

ZECHA, S. (2012), Geocaching, a tool to support environmental education!?- An explorative study. Educational Research eJournal, 2, 177-188.

ZECHA, S. \& Hof, A. (2013), Geocaching. In: BÖHN, D. \& OBERMAIER, G. (Eds.), Didaktik der Geographie - Begriffe. München.

ZECHA, S. \& SCHILLER, T. (2014), Geocaching und Umweltbildung eine mögliche Kombination? In: HAFFER, S. \& PETER, C. (Eds.), Herausforderungen in der Geographiedidaktik. Neue Medien, Kompetenzen, Leitbilder, Realbegegnungen. Gießen, 115-127.

www.educache.net (20.03.2014)

www.edunauten.net (20.03.2014)

www.opencaching.de (20.03.2014) 